\title{
A CASE REPORT ON SICKLE CELL DISEASE WITH HEMOLYTIC ANEMIA, NEPHROTIC SYNDROME AND ACUTE CHEST SYNDROME
}

Putta Suresh ${ }^{1}$, Yamini Devi Cheekatla²

\section{HOW TO CITE THIS ARTICLE:}

Putta Suresh, Yamini Devi Cheekatla. "A Case Report On Sickle Cell Disease With Hemolytic Anemia, Nephrotic Syndrome And Acute Chest Syndrome". Journal of Evolution of Medical and Dental Sciences 2015; Vol. 4, Issue 20, March 09; Page: 3540-3543, DOI: 10.14260/jemds/2015/509

\begin{abstract}
Sickle cell disease is an autoimmune hemolytic anemia due to abnormal hemoglobin. Sickling of RBCs occur due to abnormal hemoglobin which leads to vaso-occlusive crisis. This disease manifests as hemolytic anemia, acute chest syndrome, stroke, ischemic leg ulcers and nephrotic syndrome. This patient presented with hemolytic anemia, nephrotic syndrome and acute chest syndrome. This case was diagnosed by electrophoresis of hemoglobin and peripheral smear. This patient recovered with blood transfusion, antibiotics, steroids, diuretics and oxygen inhalation. Sickle cell patients have a known predisposition to bacterial infection, particularly pneumococcal infection. The most significant advance in the therapy of sickle cell anemia has been the introduction of hydroxyurea, but hydroxyurea should be considered in patients experiencing repeated episodes of acute chest syndrome. But in this patient as this is first episode, hydroxyurea was not given and he recovered well.
\end{abstract}

KEYWORDS: Autoimmune hemolytic anemia, Acute chest syndrome, Nephrotic syndrome, vasoocclusive crisis, sickle cells.

INTRODUCTION: Sickle cell disease results from a single glutamic acid to valine substitution at position 6 of the beta globin polypeptide chain. It is inherited as an autosomal recessive trait. ${ }^{1}$ The disease mainly occurs in Africans (25\% carry the gene). But is also found in India, the Middle East, and Southern Europe. ${ }^{2}$ When haemoglobin $\mathrm{S}$ is deoxygenated, the molecules of hemoglobin polymerise to form pseudocrystalline structures known as 'tactoids'. These distort the red cell membrane and produce characteristic sickle shaped cells. The polymerization is reversible when reoxygenation occurs. The distortion of the red cell membrane, however, may become permanent and the red cell 'irreversibly sickled'. This process may be enchanced or retarded by the presence of other hemoglobins. Thus, the abnormal hemoglobin $\mathrm{C}$ variant participates in the polymerization more readily than haemoglobin $\mathrm{A}$, whereas haemoglobin $\mathrm{F}$ strongly inhibits polymeriastion. These abnormalities provoke unpredictable episodes of microvascular vaso-occlusion and premature RBC destruction (hemolytic anemia). Hemolysis occurs because the spleen destroys the abnormal RBC. The rigid adherent cells also clog small capillaries and venules, causing tissue ischaemia, acute pain, and gradual end-organ damage.

This veno-occlusive component usually dominates the clinical course. Prominent manifestations include episodes of ischaemic pain, infarction in the spleen, central nervous system, bones, liver, kidneys and lungs. Most patients with sickle cell syndromes suffer from hemolytic anemia with hematocrits from $15-30 \%$ and significant reticulocytosis. Usually nephrotic syndrome and acute chest syndrome are seen as complications. Acute chest syndrome characterized by fever, chest pain, wheezing, cough, hypoxia and lung infiltrates, is a lethal complication that affects half of all the patients with sickle cell anemia. ${ }^{3}$ Repeated acute chest syndrome episodes may also predispose to 


\section{CASE REPORT}

scarring and pulmonary hypertension. ${ }^{4}$ It is unclear that the patients with sickle cell disease are more prone to nephrotic syndrome, but the histological picture of membrano-proliferative glomerulonephritis accounts for over one half of adult cases. ${ }^{5}$ Patients with sickle cell anemia adapt well to their low hemoglobin levels and regular blood transfusion is not required. ${ }^{6}$

CASE REPORT: A 20 year old male with acute onset of dyspnoea, chest pain, pedal odema, facial puffiness and fever for four days. On physical examination temperature $-102^{\circ} \mathrm{F}$, pulse rate -120 beats/min, respiratory rate -32 cycles/min, blood pressure $-120 / 82 \mathrm{mmHg}$, pallor present and anasarca present, Cardiovascular system - normal heart sounds, no murmur, Respiratory system bilateral crepitations, abdomen - hepatoslenomegaly present. Investigations shows $\mathrm{Hb}-5 \mathrm{gm} \%$, RBS - $110 \mathrm{mg} \%$, blood urea $-60 \mathrm{mg} \%$, Serum creatinine $-2.5 \mathrm{mg} \%$, 24 hours urinary protein - 3.5gm\%. ECG - sinus tachycardia, Chest X-ray PA view - bilateral infiltrates. Complete hemogram shows Normocytic normochromic anemia with sickle cells, poikilocytes, target cells, fragmented RBC and no haemoparasites.

\section{SICKLING TEST:}

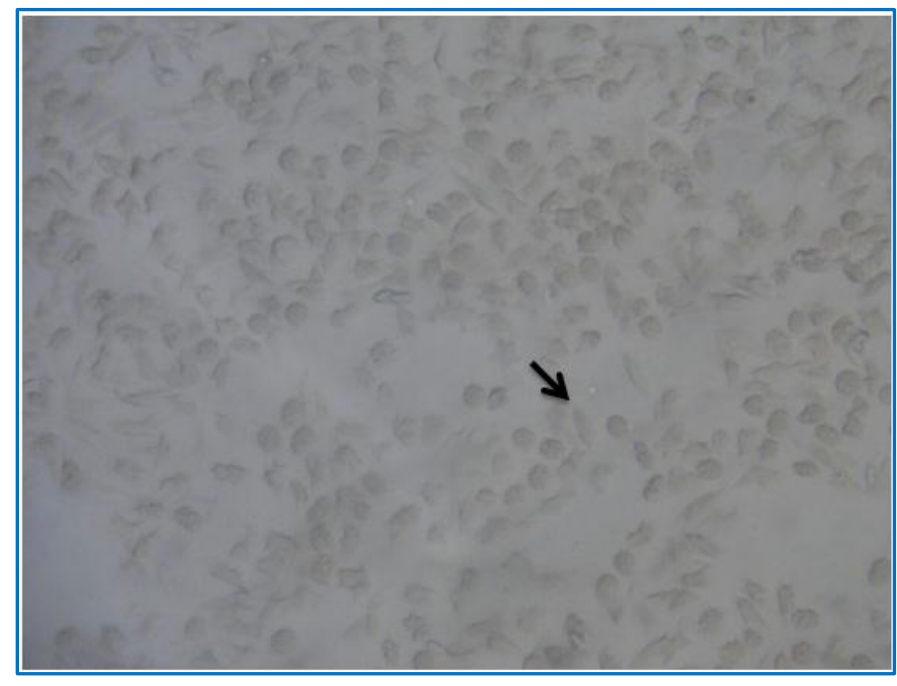

Fig. 1

HAEMOGLOBIN ELECTROPHORESIS: $\mathrm{Hb}$ A $-28.9 \%, \mathrm{Hb} \mathrm{A}-3.7 \%$, $\mathrm{Hb} \mathrm{F}-10 \%, \mathrm{Hb} \mathrm{S}-57.1 \%$, Abnormal $\mathrm{Hb}$ peak of 57.1 with retention time of $4.37 \mathrm{~min}$.

With the above hemoglobin electrophoresis and haemogram reports, this case is diagnosed as sickle cell disease with hemolytic anemia, acute chest syndrome and nephrotic syndrome. This patient treated with diuretics, antibiotics, bronchodilators, blood transfusion, intravenous albumin and oxygen inhalation. Patient recovered very well and discharged.

DISCUSSION: Sickle cell disease usually presents as vaso-occlusive crisis, acute chest syndrome, hemolytic anemia and nephrotic syndrome. This patient presented with anemia, acute chest syndrome and nephrotic syndrome. The definitive diagnosis requires hemoglobin electrophoresis to 


\section{CASE REPORT}

demonstrate the absence of $\mathrm{HbA}, 2-20 \%$ of $\mathrm{HbF}$ and the presence of $\mathrm{HbS}^{7}$ In this case hemoglobin electrophoresis shows the presence of $\mathrm{HbF}(10 \%)$ and $\mathrm{Hb} \mathrm{S}(57.1 \%)$. The peripheral blood smear is characteristically abnormal, with irreversibly sickled cells comprising 5-50\% of red cells. ${ }^{8}$ Peripheral blood smear from this patient shows sickle cells. Sickle cell patients have a known predisposition to bacterial infection, particularly pneumococcal infection.9-11 This patient treated with blood transfusion, antibiotics, steroids, diuretics and oxygen inhalation. His serum protein showed hypoalbuminemia, urine showed albuminuria, his blood pressure was normal. Patient was given steroids and intravenous albumin. Patient recovered from oedema with intravenous albumin and blood transfusion. The most significant advance in the therapy of sickle cell anemia has been the introduction of hydroxyurea, but hydroxyurea should be considered in patients experiencing repeated episodes of acute chest syndrome. ${ }^{12}$ But hydroxyurea was not given to this patient as this is first episode. With the above treatment patient recovered well, discharged and review after ten days in the 0 . P. revealed that the patient was healthy. Hence even in vaso-occlusive disorder of sickle cell disease patient's recovery is good with early diagnosis and effective treatment.

\section{REFERENCES:}

1. J. I. O. Craig, D. B. L. Mc Cleland, H.G. Watson: Sickle cell anemia -Introduction, Davidson's Principles and Practice of Medicine, Nicki R. Colladge Bsc. FRCP (Ed), Brian R. Walker Bsc M. D., FRCP (Ed), Stuart H. Ralston, M. D., FRCP, F Med Sci FRSE 21st ed., p.1028.

2. M.F. Murphy, J Wainscot \& B. T. Colvin: Sickle cell syndromes, Kumar and Clark Clinical Medicine $-5^{\text {th }}$ ed., Parveen Kumar, Michael Clark p. 430.

3. Martin H Steinberg: Sickle cell disease and other hemoglobinopathies, Goldman's Cecil Medicine, Arend, Armijage, et. al, 24th ed., p.1070.

4. Powars D, Weidman JA, Odom-Maryon T, Niland JC, Johnson C: Sickle cell chronic lung disease: Prior morbidity and the risk of pulmonary failure. Medicine 67-66, 1988.

5. G. R. Serjeant: Sickle cell disease and the kidney, Oxford textbook of Medicine, David A. Warrell, Timothy M. Cox, John D. Firth $5^{\text {th }}$ ed.vol.3 p. 4070.

6. D.J Weatherall: Disorders of the synthesis or function of hemoglobin, David A. Warrell, Timothy M.Cox, John D. Firth: Oxford textbook of Medicine, $5^{\text {th }}$ ed. Vol. 3, p. 4440.

7. J.I.O. Craig, D. B. L. Mc Cleland, H.G. Watson: Sickle cell anemia -Investigations, Davidson's Principles and Practice of Medicine, Nicki R. Colladge Bsc. FRCP (Ed), Brian R. Walker Bsc M. D., FRCP (Ed), Stuart H. Ralston, M. D., FRCP, F Med Sci FRSE 21 ${ }^{\text {st }}$ ed., p.1028.

8. Charles A. Linker,M. D.: Sickle cell anemia - laboratory findings, Current Medical Diagnosis and Treatment, (2007), Stephen J. Mc PHEE, Maxine A. Papadaki, M. D., Lawrence M. Tierry, Jr., M. D., $46^{\text {th }}$ ed., p. 505 .

9. Barrett - Connor E: Bacterial infection and sickle cell anemia. An analysis of 250 infections in 166 patients and a review of the literature, Medicine 50: 97, 1971.

10. Baehner RL, Provisor AJ: Bacterial infections in sickling disorders, in Schwartz E (ed): Hemoglobinopathies in children. Littleton, MA, PSG Publishing Co, 1980, p. 249.

11. De Ceulaer K, Pagliuca A, Forbes M, Maude GH, Sergeant BE, Sergeant GR: Recurrent infections in sickle cell disease: Haemotolgical and immune studies. Clin Chim Acta 148: 161, 1985.

12. Dan. L. Longo: Treatment of sickle cell syndromes, Harrison's Principles of Internal medicine, Anthony S. Fauci, M. D., Dennis L. Casper, M.D., Dan L. Longo, M. D., et. al., 17th ed. Vol 1, p.639. 


\section{CASE REPORT}

\section{AUTHORS: \\ 1. Putta Suresh \\ 2. Yamini Devi Cheekatla \\ PARTICULARS OF CONTRIBUTORS: \\ 1. Associate Professor, Department of General Medicine, S. V. Medical College, Tirupati. \\ 2. Assistant Professor, Department of Anatomy, S. V. Medical College, Tirupati.}

FINANCIAL OR OTHER

COMPETING INTERESTS: None

\section{NAME ADDRESS EMAIL ID OF THE CORRESPONDING AUTHOR:}

Dr. Putta Suresh, Associate Professor, Department of General Medicine,

S. V. Medical College,

S. V. R. R. G. G. Hospital, Tirupati-517507, Chittor District, Andhra Pradesh.

E-mail: bujjigarusuresh@gmail.com

Date of Submission: 13/02/2015.

Date of Peer Review: 14/02/2015.

Date of Acceptance: 26/02/2015.

Date of Publishing: 09/03/2015. 